\title{
SHORT-TERM SELECTION FOR BODY WEIGHT AND GROWTH RATE IN JAPANESE QUAIL 2. CORRELATED RESPONSES
}

\author{
Gihan, S. Farahat; Ensaf, A. EI Full; Mohamed, H. Abdel Fattah*; Nabel, \\ A. Hataba* and Mohamed, A. Khalifa \\ Poultry Production Dept., Faculty of Agriculture, Fayoum Univ., Egypt. \\ *Animal Production Research Institute, ARC, Dokki, Egypt.
}

\section{ABSTRACT:}

Three quail lines were used in this work to evaluate the correlated responses of growth and some fitness traits in Japanese quail after mass selection for increased either weight or growth rate: $\mathrm{HBW}_{42}$ line was selected for high body weight at 42 days of age, $\mathrm{HGR}_{1-42}$ line was selected for high growth rate during the period from one-day to 42 days of age and randombred control line RBC was used as non-selected pedigreed population. The results obtained can be summarized as follows:

The highest correlated responses of body weights were attained in the $1^{\text {st }}$ generation for $\mathrm{BW}_{1}$ and $\mathrm{BW}_{35}$ associated with faster $\mathrm{GR}_{21-42}$. The highest fertility and hatchability percentages either calculated from total egg set (HTE\%) or fertile eggs (HFE\%) were obtained after one generation of selection. Asymmetrical correlated responses between the two sexes were found and were not stable throughout the three generations. Selection for $\mathrm{HBW}_{42}$ resulted in increases in body weights at 14,21, 28 and 35 days of age and faster growth rate during the period from 1-21 days than other lines. However, the $\mathrm{HGR}_{1-42}$ line had heavier body weights at 7 and 42 days of age than other lines. Significant line differences favoring $\mathrm{HGR}_{1-42}$ followed by $\mathrm{HBW}_{42}$ were attained for fertility\%, HTE\% and HFE\%. Correlated responses in the line $\mathrm{HGR}_{1-42}$ were higher but insignificant than that for the $\mathrm{HBW}_{42}$ line for males and females. However, females had higher correlated response in $\mathrm{BW}_{7}$ with significant sex differences in the $\mathrm{HBW}_{42}$ and $\mathrm{HGR}_{1-42}$ lines. Generally, the realized correlated responses of all studied growth traits in males were positive and higher than their expected correlated responses. The highest realized correlated responses were 4.97 in $\mathrm{BW}_{35}$ of the $\mathrm{HBW}_{42}$ line and 4.76 in $\mathrm{BW}_{42}$ of the $\mathrm{HGR}_{1-42}$ line. Realized correlated responses in all body weights from 7 up to 42 days of age for the HGR $_{1-42}$ line, except $\mathrm{BW}_{1}$ were significantly higher and positive than their expected estimates, whereas the realized correlated responses in growth rate traits of this line were insignificantly different than their expected estimates. The highest correlated responses for females were 7.21 and 5.86 for $\mathrm{BW}_{21}$ in the $\mathrm{HBW}_{42}$ and $\mathrm{HGR}_{1-42}$ lines, respectively. The realized correlated responses were insignificantly lower than expected estimates for all fitness traits in the line selected for $\mathrm{HBW}_{42}$. Similar trend was observed for fitness traits except HTE\%, which indicated highly significant differences favoring realized correlated responses as a result of selection for $\mathrm{HGR}_{1-42}$. It can be concluded that selection for high growth rate is more effective than selection for body weight because both insignificantly differed from each other for all growth traits and the survivability during the periods from 1-21 and 1-42 days of age. Besides, there are significant differences favoring $\mathrm{HGR}_{1-42}$ line for fertility $\%$ and hatchability $\%$ which calculated as a percentage of total eggs or as a percentage of fertile eggs, which can be used as additional indirect goals from selection in that line.

Fayoum J. Agric. Res. \& Dev., Vol. 21, No. 1, January, 2007 
Key words: Selection, correlated response, body weight, growth rate, Japanese quail.

\section{INTRODUCTION}

Selection experiments for improving a certain trait have frequently resulted in changing one or more of unselected traits. These associated changes are due to the genetic effects, environmental influences and a combination of both. Pleiotropy is probably the main cause of permanent genetic associations while these caused by linkage are transient (Lerner, 1958 and Falconer, 1989). Either phenotypically or genetically, there are high associations between body weights obtained at various ages prior to sexual maturity. Positive correlations, which considered part whole relationships, during the juvenile growth period should be expected (Siegel 1963). Early growth rate was correlated with other body weight measurements as reviewed by Marks (1979). Similar results were obtained by several investigators (Anthony et al., 1986, Bahie El Deen, 1991 and 1994, El Fiky, 1991, Kosba and Soliman, 1992, El Sayed et al., 1995, Tawfuek, 1995, Anthony et al., 1996 and Badawy et al., 1997, Emmerson, 1997 and Buyse et al., 2001). Yet it is clear that the main correlated response to selection for growth at, or near, the inflection point of the growth curve is early exponential growth rate, generally described as occurring during the first two post hatched weeks (Barbato, 1991 and 1992).

It has long been known that selection for two traits having a negative genetic correlation will result in a subsequent reduction in fitness (Decuypere et al., 2003) with a reduction in immunocomptence and disease resistance ( $\mathbf{L i}$ et al., 2000). Moreover, their reproductive potential is adversely affected (Havenstein et al., 1994, Nicholson, 1998 and Decuypere et al., 2003). Thus, further breeding should consider not only how to increase production but also how to alleviate correlated side effects by extending or changing selection goals for obvious economic reasons. Selection for high four-week body weight resulted in decreases in fertility and hatchability percentages, but the declines in hatchability were less during selection for high body weight in Japanese quail (Marks, 1979). Divergent selection for four-week body weight under two nutritional treatments resulted in hatchability decrease as found by Darden and Marks (1988). However, Nestor and Bacon (1982) reported that fertility and hatchability insignificantly differed among strains divergently selected for four-week body weight and yolk precursor in the fifth generation of selection. Fertility and hatchability in the divergently selected lines for body weight at six-weeks of age over 65 generations were significantly lower than those in the control line (Suda and Okamoto, 2003).

It is important to measure the actual changes occurred in one trait as a result of selection program for another trait. This study was done to evaluate the correlated responses over three generations of selection for either high body weight or growth rate on some growth and fitness traits in Japanese quail.

\section{MATERIALS AND METHODS}

The experimental work of the present study was carried out at the Poultry Research Center, Faculty of Agriculture, Fayoum University. It lasted for three generations after establishing the base population. Three quail lines were used in this study. Line $\mathrm{HBW}_{42}$ was established for high body weight at 42 days of age, line $\mathrm{HGR}_{1-42}$ was established for high growth rate during the

Fayoum J. Agric. Res. \& Dev., Vol. 21, No. 1, January, 2007 
SHORT-TERM SELECTION FOR BODY WEIGHT AND GROWTH.. 195

period from one-day to 42 days of age and a randombred control line (RBC) was maintained as non-selected pedigreed population. Details of the origin, maintenance, rearing and breeding design of the $\mathrm{HBW}_{42}, \mathrm{HGR}_{1-42}$, and RBC lines were previously outlined by Abdel Fattah (2006).

The following criteria were measured or calculated

1. Body weight at hatch, $7,14,21,28,35$, and 42 days of age $\left(\mathrm{BW}_{1}, \mathrm{BW}_{7}\right.$, $\mathrm{BW}_{14}, \mathrm{BW}_{21}, \mathrm{BW}_{28}, \mathrm{BW}_{35}$, and $\mathrm{BW}_{42}$, respectively) were individually recorded to the nearest $0.01 \mathrm{~g}$.

2. Growth rates during the periods from 1-21, 21-42, and 1-42 days of age ( $\mathrm{GR}_{1-21}, \mathrm{GR}_{21-42}$, and $\mathrm{GR}_{1-42}$, respectively) were calculated according to Brody (1945) using the following formula:

$$
\mathbf{G R}=\left[\mathbf{W}_{2}-\mathbf{W}_{1} /{ }^{1} / 2\left(\mathbf{W}_{2}+\mathbf{W}_{1}\right)\right] \times 100
$$

where: $\mathbf{W}_{\mathbf{1}}$ is the weight at the beginning and $\mathbf{W}_{\mathbf{2}}$ is the weight at the end of the period.

3. Fertility $\%$ and hatchability\% which calculated as a percentage of total eggs $(\mathrm{HTE} \%)$ or as a percentage of fertile eggs (HFE\%).

4. Mortality data were collected and defined as the time from hatch to the date the bird died to calculate the survivability during the periods from 1-21 $\left(\mathrm{S}_{3} \%\right)$ and 1-42 days of age $\left(\mathrm{S}_{6} \%\right)$.

\section{Statistical analyses}

Means and standard errors of all studied correlated traits were

subjected to analysis using three ways ANOVA with generation, sex and line as main effects, according to the following model:

$$
Y_{i j k}=\mu+G_{i}+L_{j}+S_{k}+e_{i j k}
$$

where: $\boldsymbol{\mu}$ is the common mean, $\mathbf{G}$ is the effect of $i^{\text {th }}$ generation, $\mathbf{L}_{\mathbf{j}}$ is the effect of $j^{\text {th }}$ line, $\mathbf{S}_{\mathbf{k}}$ is the effect of $\mathrm{k}^{\text {th }}$ sex and $\mathbf{e}_{\mathbf{i j k}}$ : random error term, using the GLM procedure of SPSS program (SPSS, 1999). Means were compared for main effects by Duncan's multiple range test (Duncan, 1955), when significant $\mathrm{F}$ values were obtained $(\mathrm{P}<0.05)$.

Expected correlated responses were calculated according to Falconer (1989) as follows:

$$
C R_{y}=i h_{x} h_{y} \mathbf{r}_{g} \delta_{p(Y)}
$$

where: $\mathbf{h}_{\mathbf{X}}, \mathbf{h}_{\mathbf{Y}}$ is the square root of heritabilites of $\mathrm{X}$ and $\mathrm{Y}$ traits, $\mathbf{r g}$ is the genetic correlation between $\mathrm{X}$ and $\mathrm{Y}$ traits, $\boldsymbol{\delta} \mathbf{p}_{(\mathbf{y})}$ is the phenotypic standard deviation of $\mathrm{Y}$ trait and $\mathbf{i}$ is the selection intensity for trait $\mathrm{X}$. The expected, realized and cumulative values for correlated responses in the present study were calculated according to Falconer (1989). Also, pairing t-test was used to compare all the realized and expected values for the all correlated responses to selection.

\section{RESULTS AND DISCUSSION}

Means for body weight at different ages, growth rates during different periods of growth and fitness traits are presented in Table 1.

\section{Generation effect}

Significant differences due to generation effect were found for $\mathrm{BW}_{1}$, $\mathrm{BW}_{7}, \mathrm{BW}_{14}, \mathrm{BW}_{35}$ and growth rates during different periods studied. The highest body weights were attained in the first generations for $\mathrm{BW}_{1}$ and $\mathrm{BW}_{35}$ accompanied with faster growth rate during the period from 21 to 42 days of age $(8.14,168.71 \mathrm{~g}$ and $65.7 \%)$. However, the second generation had heavier body weights at all ages, except at hatch and 35 days of age, associated with

Fayoum J. Agric. Res. \& Dev., Vol. 21, No. 1, January, 2007 
faster growth rate during 1- 21 and 1- 42 days of age than other generations $(\mathrm{P} \leq 0.05$, Table 1$)$.

The highest fertility, HTE\% and HFE\% were obtained in the first generation of selection $(82.88,71.53$ and $87.27 \%$, respectively). Similar trends were reported by Marks (1979), Darden and Marks (1988) and Suda and Okamoto (2003). However, no generation effects through selection generations had shown on percentages of $\mathrm{S}_{3} \%$ and $\mathrm{S}_{6} \%$ as shown in Table 1 .

Line effect

Significant line differences $(\mathrm{P} \leq 0.05)$ were found for growth traits at all ages, except hatch weight, and growth rate during the period from 1-21 days of age. The selected lines had significantly heavier body weights at these ages than their controls, whereas they insignificantly differed from each other for all body weight traits. Similarly, the RBC line had significant slower growth rates during 1-21 and 1-42 days of age periods than the selected lines (Table 1). Selection for high 42-day body weight resulted in significantl increases in body weights at 14,21, 28 and 35 days of age and faster growth rate during the period from 1-21 days of age in $\mathrm{HBW}_{42}$ line $(55.66,97.45,136.49$, $169.22 \mathrm{~g}$ and $169.9 \%$ ) than the RBC and HGR $_{1-42}$ lines as shown in Table 1. However, the $\mathrm{HGR}_{1-42}$ had heavier body weights at seven and 42 days of age (25.29 and $188.91 \mathrm{~g}$ ) than the RBC and $\mathrm{HBW}_{42}$ lines. These results are in accordance with those reported by Anthony et al. (1986) who illustrated that selection for rapid growth at any age was effective in increasing body weight when compared to the control line.

Significant line differences favoring $\mathrm{HGR}_{1-42}$ line followed by $\mathrm{HBW}_{42}$ line were attained for fertility\%, HTE\% and HFE\% (83.34, 65.85 and $79.72 \%$ vs $80.97,62.23$ and $76.62 \%$, respectively) as shown in Table 1 . Whereas, the lowest estimates in these respects were indicated by the control line $(\mathrm{P} \leq 0.05)$. Opposite trend was reported by Suda and Okamoto (2003) that fertility and hatchability in the divergently selected lines for body weight at six-weeks of age over 65 generations were significantly lower than those in the control line. This different results is mainly due to the longer period of selection in the work of Suda and Okamoto (2003). However, line insignificantly affected $\mathrm{S}_{3} \%$ and $\mathrm{S}_{6} \%$ as illustrated in Table 1 .

Sex effect

Sex significantly influenced body weights at 21,28, 35 and 42 days of age favoring females $(97.28,137.22,171.14$ and $192.87 \mathrm{~g}$ vs $95.50,133.54$, 165.31 and $183.18 \mathrm{~g}$, respectively) as shown in Table 1. Similarly, females had higher $(\mathrm{P} \leq 0.01)$ growth rates during the periods $21-42$ and $1-42$ days than males (66.2 and $184.2 \%$ vs 63.2 and $183.4 \%$, respectively). Similar results were reported by Marks (1996), Nestor et al. (1996), Shalan (1998) and Bahie El Deen (2003). This divergence in body weight may be attributed to an acceleration of weight gain by females just prior to laying their first egg (Sefton and Siegel, 1974).

Realized correlated responses for growth traits

Realized correlated responses to selection for $\mathrm{BW}_{42}$ and $\mathrm{GR}_{1-42}$ are presented in Table 2 for males and females and in the Figures from 1 to 3 for the combined sex. The response is presented as an absolute deviation $(\mathrm{g})$ and as a percent deviation from the RBC line. Differences between the correlated responses of males and females were not constant throughout the three generations. The overall correlated response (as a percent deviation from RBC line) to selection for $\mathrm{HBW}_{42}$ by the $3^{\text {rd }}$ generation indicated that males had a

Fayoum J. Agric. Res. \& Dev., Vol. 21, No. 1, January, 2007 
SHORT-TERM SELECTION FOR BODY WEIGHT AND GROWTH.. 197

Table 1

Fayoum J. Agric. Res. \& Dev., Vol. 21, No. 1, January, 2007 
Gihan, S. Farahat; et al.

Table 2

Fayoum J. Agric. Res. \& Dev., Vol. 21, No. 1, January, 2007 
SHORT-TERM SELECTION FOR BODY WEIGHT AND GROWTH.. 199

Fig. 1

Fayoum J. Agric. Res. \& Dev., Vol. 21, No. 1, January, 2007 
Gihan, S. Farahat; et al.

Fig. 2

Fayoum J. Agric. Res. \& Dev., Vol. 21, No. 1, January, 2007 
SHORT-TERM SELECTION FOR BODY WEIGHT AND GROWTH.. 201

Fig. 3

Fayoum J. Agric. Res. \& Dev., Vol. 21, No. 1, January, 2007 
higher percent increase in all growth traits except $\mathrm{BW}_{1}, \mathrm{BW}_{14}$ and $\mathrm{GR}_{21-42}$ whereas females exceeded the RBC line by $1.483 \%, 3.756 \%$ and $0.743 \%$, respectively. Males exceeded the RBC line by 3.407\%, 7.166\%, 6.498\%, $5.621 \%, 1.311 \%$ and $0.415 \%$ for $\mathrm{BW}_{7}, \mathrm{BW}_{21}, \mathrm{BW}_{28}, \mathrm{BW}_{35}, \mathrm{GR}_{1-21}$ and $\mathrm{GR}_{1-42}$, respectively (Table 2). This may be due to the fact that selection pressure was much higher on the sire side than the dam side. Similar asymmetry in response to selection for increased broiler body weight between the two sexes was found by Khan et al. (1975), Benoff and Renden (1983) and El Gindy (1984). The direct response to selection for $\mathrm{HBW}_{42}$ was greater than the correlated responses which accompanied selection. This result confirms those of El Hossari (1977) who indicated that the direct response to selection for any trait was greater than the correlated responses. Similarly, asymmetry in response to selection between the two sexes was found. The overall correlated response (as a percent deviation from RBC line) to selection for $\mathrm{HGR}_{1-42}$ by the $3^{\text {rd }}$ generation indicated that males had a higher percent increase in body weight than females at $7,14,21,28,35$ and 42 days of age $(4.409,3.170$, $5.825,5.386,4.739$ and 5.228 vs $2.151,2.964,3.574,4.126,4.365$ and 4.758 $\%$, respectively) and growth rate during the period from 1 to 21 days of age $(0.955$ vs 0.290$)$. Whereas, females exceeded the RBC line by $0.106 \mathrm{~g}$ $(1.508 \%)$ in $\mathrm{BW}_{1}$ and $\mathrm{GR}_{21-42} 0.010(1.586 \%)$ as shown in Table 2.

Except, a significant regression coefficient of $-2.067 \%$ for females $\mathrm{BW}_{7}$ response on generation number in the selected line for $\mathrm{HBW}_{42}$ the regression coefficients were insignificant (Table 2).

There were significant regression coefficients of $1.526 \%$ for males $\mathrm{BW}_{42}$ and $48.064 \%$ for males $\mathrm{GR}_{1-21}$ response to selection for $\mathrm{HGR}_{1-42}$ line on generation number as shown in Table 2.

\section{Realized cumulative correlated responses for growth traits}

Realized cumulative correlated responses for growth traits of the selected lines as percent of their RBC are presented in Table 3. There were inconsistent sex differences for various growth traits across generations. Males had positive and higher correlated responses in $\mathrm{BW}_{1}$ than females to selection for $\mathrm{HBW}_{42}$ or $\mathrm{HGR}_{1-42}$ (1.8 and $3.1 \%$ vs -0.50 and $1.20 \%$, respectively). The correlated responses in the line selected for $\mathrm{HGR}_{1-42}$ were higher but insignificant than that for the line selected for $\mathrm{HBW}_{42}$ for males, females and combined sexes. However, females had higher correlated responses in $\mathrm{BW}_{7}$ of $7.80 \mathrm{~g}(10.30 \%)$ vs $3.40 \mathrm{~g}(3.80 \%)$ and $\mathrm{BW}_{21}$ of $14.60 \mathrm{~g}(12.50 \%)$ vs $7.20 \mathrm{~g}(5.60 \%)$ with significant sex differences in the $\mathrm{HBW}_{42}$ and $\mathrm{HGR}_{1-42}$ lines. For the combined sexes, the correlated responses in $\mathrm{HBW}_{42}$ line were insignificantly differed than those of the $\mathrm{HGR}_{1-42}$ line across the three generations of selection. However, significant sex differences for both $\mathrm{HBW}_{42}$ and $\mathrm{HGR}_{1-42}$ lines were found for $\mathrm{BW}_{7}, \mathrm{BW}_{21}$. Similar trends of significant sex differences were observed for $\mathrm{BW}_{28}$ and $\mathrm{BW}_{42}$ in the $\mathrm{HGR}_{1-42}$ line as shown in Table 3. The highest resultant response in $\mathrm{BW}_{21}$ of the combined sexes was $11.3 \%$ in the line selected for $\mathrm{HBW}_{42}$, whereas the highest correlated responses of the combined sexes were $9.7 \%$ in $\mathrm{BW}_{28}$ and $\mathrm{BW}_{42}$ in the $\mathrm{HGR}_{1-42}$ line (Table 3).

\section{Comparison among expected and realized correlated responses Expected and realized correlated responses for growth traits}

The realized correlated responses for the generations average of all studied growth traits in males were positive and higher than their expected correlated responses (Table 4). The realized correlated responses in $\mathrm{BW}_{7}$ and

Fayoum J. Agric. Res. \& Dev., Vol. 21, No. 1, January, 2007 
Table 3. Realized cumulative correlated responses for growth traits by generation for $\mathrm{HBW}_{42}$ and $\mathrm{HGR}_{1-42}$ lines as a percent deviation from their RBC line in Japanese quail.

\begin{tabular}{|c|c|c|c|c|c|c|c|}
\hline \multirow{2}{*}{ Trait } & \multirow{2}{*}{$\mathbf{G}$} & \multicolumn{2}{|c|}{ Male } & \multicolumn{2}{|c|}{ Female } & \multicolumn{2}{|c|}{ Combined sexes } \\
\hline & & $\mathrm{HBW}_{42}$ & HGR $_{1-42}$ & $\mathrm{HBW}_{42}$ & HGR $_{1-42}$ & $\mathrm{HBW}_{42}$ & HGR $_{1-42}$ \\
\hline \multirow{4}{*}{$\mathrm{BW}_{1}$} & 1 & 0.36 & 0.73 & -0.85 & -1.22 & -0.24 & -1.46 \\
\hline & 2 & 0.52 & 1.44 & -1.57 & 1.05 & -0.26 & 0.13 \\
\hline & 3 & 4.51 & 7.11 & 0.92 & 3.68 & 3.08 & 3.75 \\
\hline & $\mathbf{X}$ & 1.80 & 3.10 & -0.50 & 1.20 & 0.90 & 0.80 \\
\hline \multirow{4}{*}{$\mathbf{B W}_{7}$} & 1 & 0.16 & 1.35 & 5.15 & 6.09 & 2.96 & 4.23 \\
\hline & 2 & 4.45 & 3.64 & 8.62 & 12.07 & 6.84 & 8.37 \\
\hline & 3 & 5.67 & 6.54 & 9.75 & 12.59 & 7.87 & 9.84 \\
\hline & $\mathbf{X}$ & 3.40 & 3.80 & 7.80 & 10.30 & 5.90 & 7.50 \\
\hline \multirow{4}{*}{$\mathrm{BW}_{14}$} & 1 & 1.31 & 2.69 & 4.84 & 4.75 & 3.35 & 3.94 \\
\hline & 2 & 10.57 & 6.20 & 7.80 & 8.71 & 9.46 & 7.79 \\
\hline & 3 & 11.33 & 8.96 & 9.66 & 9.40 & 10.70 & 9.32 \\
\hline & $\mathbf{X}$ & 7.70 & 6.00 & 7.40 & 7.60 & 7.80 & 7.00 \\
\hline \multirow{4}{*}{$\mathbf{B W}_{21}$} & 1 & 1.29 & 2.36 & 8.28 & 7.97 & 5.20 & 5.49 \\
\hline & 2 & 8.31 & 3.53 & 13.94 & 12.09 & 11.58 & 8.18 \\
\hline & 3 & 11.98 & 10.77 & 21.6 & 17.52 & 17.1 & 14.3 \\
\hline & $\mathbf{X}$ & 7.20 & 5.60 & 14.60 & 12.50 & 11.30 & 9.30 \\
\hline \multirow{4}{*}{$\mathrm{BW}_{28}$} & 1 & 3.46 & 4.38 & 7.68 & 6.41 & 5.71 & 5.40 \\
\hline & 2 & 11.25 & 7.39 & 12.97 & 11.26 & 12.32 & 9.41 \\
\hline & 3 & 13.59 & 12.35 & 19.54 & 16.21 & $16 . .86$ & 14.32 \\
\hline & $\mathbf{X}$ & 9.40 & 8.00 & 13.40 & 11.30 & 6.00 & 9.70 \\
\hline \multirow{4}{*}{$\mathbf{B W}_{35}$} & 1 & 4.29 & 4.07 & 6.72 & 6.02 & 5.54 & 4.98 \\
\hline & 2 & 10.06 & 6.63 & 9.98 & 9.88 & 10.20 & 8.33 \\
\hline & 3 & 15.11 & 13.25 & 16.98 & 14.32 & 16.12 & 13.61 \\
\hline & $\mathbf{X}$ & 9.80 & 8.00 & 11.20 & 10.10 & 10.60 & 9.00 \\
\hline \multirow{4}{*}{$\mathrm{BW}_{42}$} & 1 & & 3.28 & & 5.12 & & 4.01 \\
\hline & 2 & & 8.04 & & 10.60 & & 9.66 \\
\hline & 3 & & 14.32 & & 17.07 & & 15.44 \\
\hline & $\mathbf{X}$ & & 8.50 & & 10.9 & & 9.70 \\
\hline \multirow{4}{*}{$\mathbf{G R}_{1-21}$} & 1 & 0.30 & 0.84 & 1.93 & 1.93 & 1.14 & 1.44 \\
\hline & 2 & 4.12 & 3.52 & 2.95 & 2.06 & 3.54 & 2.83 \\
\hline & 3 & 4.34 & 3.76 & 4.03 & 3.14 & 4.08 & 3.37 \\
\hline & $\mathbf{X}$ & 2.90 & 2.70 & 3.00 & 2.40 & 2.90 & 2.50 \\
\hline \multirow{4}{*}{$\mathbf{G R}_{21-42}$} & 1 & 3.94 & 1.31 & 1.28 & 1.28 & 2.73 & 1.77 \\
\hline & 2 & 5.55 & 6.20 & 1.36 & 3.93 & 3.62 & 3.78 \\
\hline & 3 & 16.24 & 16.56 & 4.06 & 10.08 & 4.51 & 5.29 \\
\hline & $\mathbf{X}$ & 8.60 & 8.00 & 2.20 & 5.10 & 3.60 & 3.61 \\
\hline \multirow{4}{*}{$\mathbf{G R}_{1-42}$} & 1 & 0.43 & & 0.60 & & 0.49 & \\
\hline & 2 & 0.82 & & 0.98 & & 0.87 & \\
\hline & 3 & 0.92 & & 1.31 & & 1.09 & \\
\hline & $\mathbf{X}$ & 0.70 & & 1.00 & & 0.80 & \\
\hline
\end{tabular}

$\mathrm{HBW}_{42}$ : selected line for higher 42-day body weight, $\mathrm{HGR}_{1-42}$ : selected line for higher 1- 42-day growth rate. BW: body weight, GR: Growth rate.

$\mathrm{X}$ : unweighted mean, G: generation.

Fayoum J. Agric. Res. \& Dev., Vol. 21, No. 1, January, 2007 
Table 4. Expected and realized correlated responses for growth traits for males in $\mathrm{HBW}_{42}$ and $\mathrm{HGR}_{1-42}$ lines by generation in Japanese quail.

\begin{tabular}{|c|c|c|c|c|c|c|c|c|c|c|c|}
\hline \multirow[b]{2}{*}{ Trait } & \multirow[b]{2}{*}{$\begin{array}{l}\text { Correlated } \\
\text { response }\end{array}$} & \multicolumn{5}{|c|}{$\mathrm{HBW}_{42}$} & \multicolumn{5}{|c|}{ HGR $_{1-42}$} \\
\hline & & $\mathbf{G}_{1}$ & $\mathbf{G}_{2}$ & $\mathbf{G}_{3}$ & $\mathbf{X}$ & $\mathbf{b}$ & $\mathbf{G}_{1}$ & $\mathbf{G}_{2}$ & $\mathbf{G}_{3}$ & $\mathbf{X}$ & $\mathbf{b}$ \\
\hline \multirow[b]{2}{*}{$\mathbf{B W}_{1}$} & Expected & 0.53 & 0.11 & 0.02 & 0.22 & $-0.255^{\mathrm{NS}}$ & -0.08 & -0.31 & -0.27 & -0.22 & $-0.131^{\mathrm{NS}}$ \\
\hline & $\begin{array}{l}\text { Realized } \\
\text { t-pairing }\end{array}$ & 0.36 & 0.13 & $\begin{array}{r}0.397 \\
\text { NS }\end{array}$ & 0.29 & & 0.73 & 0.66 & $\begin{array}{r}5.61 \\
\text { NS }\end{array}$ & 2.33 & \\
\hline \multirow[b]{2}{*}{$\mathbf{B W}_{7}$} & Expected & 1.54 & 0.27 & -1.39 & 0.14 & $-1.465^{*}$ & -0.15 & 0.08 & -0.42 & -0.16 & $-0.135^{\mathrm{NS}}$ \\
\hline & $\begin{array}{l}\text { Realized } \\
\text { t-pairing }\end{array}$ & 0.16 & 4.28 & $\begin{array}{r}1.15 \\
*\end{array}$ & 1.86 & & 1.35 & 2.30 & 2.84 & 2.16 & \\
\hline \multirow[b]{2}{*}{$\mathrm{BW}_{14}$} & Expected & 2.32 & 1.04 & -2.48 & 0.29 & $-2.400^{\mathrm{NS}}$ & 0.17 & 1.74 & -1.71 & 0.07 & $-0.940^{\mathrm{NS}}$ \\
\hline & $\begin{array}{l}\text { Realized } \\
\text { t-pairing }\end{array}$ & 1.31 & 9.21 & $\begin{array}{r}0.72 \\
\text { NS }\end{array}$ & 3.75 & & 2.69 & 3.41 & $\begin{array}{r}2.74 \\
\text { NS }\end{array}$ & 2.95 & \\
\hline \multirow[b]{2}{*}{$\mathbf{B W}_{21}$} & Expected & 3.62 & 2.74 & -2.85 & 1.17 & $-3.240^{\mathrm{NS}}$ & 0.57 & 3.05 & -0.31 & 1.10 & $-0.440^{\mathrm{NS}}$ \\
\hline & $\begin{array}{l}\text { Realized } \\
\text { t-pairing }\end{array}$ & 1.29 & 7.01 & $\begin{array}{r}3.55 \\
\text { NS }\end{array}$ & 3.95 & & 2.36 & 1.15 & $\begin{array}{r}7.20 \\
\text { NS }\end{array}$ & 3.57 & \\
\hline \multirow[b]{2}{*}{$\mathrm{BW}_{28}$} & Expected & 2.57 & 2.69 & -6.79 & -0.51 & $-4.680^{\mathrm{NS}}$ & 0.56 & 1.95 & -0.12 & 0.79 & $-0.340^{\mathrm{NS}}$ \\
\hline & $\begin{array}{l}\text { Realized } \\
\text { t-pairing }\end{array}$ & 3.46 & 7.83 & $\begin{array}{r}2.36 \\
*\end{array}$ & 4.55 & & 4.38 & 3.03 & $\begin{array}{r}4.96 \\
\text { NS }\end{array}$ & 4.12 & \\
\hline \multirow[b]{2}{*}{$\mathbf{B W}_{35}$} & Expected & 0.85 & 1.67 & -9.76 & -2.41 & $-5.305^{\mathrm{NS}}$ & 0.38 & 3.60 & -0.28 & 1.23 & $0.050^{\mathrm{NS}}$ \\
\hline & $\begin{array}{l}\text { Realized } \\
\text { t-pairing }\end{array}$ & 4.298 & 5.65 & $\begin{array}{r}4.97 \\
\text { NS }\end{array}$ & 4.97 & & 4.07 & 2.44 & $\begin{array}{r}6.57 \\
\text { NS }\end{array}$ & 4.36 & \\
\hline \multirow[b]{3}{*}{$\mathbf{G R}_{1-21}$} & $\begin{array}{l}\text { Expected } \\
\text { Realized } \\
\text { t-pairing }\end{array}$ & & & & & & $\begin{array}{l}0.21 \\
3.28\end{array}$ & $\begin{array}{l}1.43 \\
4.67\end{array}$ & $\begin{array}{r}-1.74 \\
6.33 \\
\text { NS }\end{array}$ & $\begin{array}{c}-0.03 \\
4.76\end{array}$ & $-0.945^{\mathrm{NS}}$ \\
\hline & Expected & 0.003 & 0.04 & -.004 & 0.01 & $-0.004^{\mathrm{NS}}$ & 0.003 & 0.019 & 0.011 & 0.01 & $-0.785^{\mathrm{NS}}$ \\
\hline & $\begin{array}{l}\text { Realized } \\
\text { t-pairing }\end{array}$ & 0.30 & 3.82 & $\begin{array}{c}0.35 \\
\text { NS }\end{array}$ & 1.29 & & 0.84 & 2.67 & 0.35 & 1.29 & \\
\hline \multirow[b]{2}{*}{$\mathbf{G R}_{21-42}$} & Expected & -0.025 & -0.01 & -0.023 & -0.003 & $-0.001^{\mathrm{NS}}$ & -0.005 & -0.012 & 0.009 & -0.003 & $-2.181^{\mathrm{NS}}$ \\
\hline & $\begin{array}{l}\text { Realized } \\
\text { t-pairing }\end{array}$ & 3.94 & 1.63 & $\begin{array}{r}1.59 \\
\text { NS }\end{array}$ & 2.06 & & 1.31 & 1.68 & $\begin{array}{r}3.18 \\
\text { NS }\end{array}$ & 2.06 & \\
\hline \multirow{2}{*}{$\mathbf{G R}_{1-42}$} & Expected & -0.010 & $\begin{array}{c}- \\
0.001\end{array}$ & -0.027 & -0.013 & $-0.009^{\mathrm{NS}}$ & & & & & \\
\hline & $\begin{array}{l}\text { Realized } \\
\text { t-pairing }\end{array}$ & 0.43 & 0.38 & $\begin{array}{c}0.11 \\
\mathbf{N S} \\
\end{array}$ & 0.31 & & & & & & \\
\hline
\end{tabular}

Fayoum J. Agric. Res. \& Dev., Vol. 21, No. 1, January, 2007 
$\mathrm{BW}_{28}$ were statistically differed than their expected estimates. The highest realized correlated responses were 4.97 in $\mathrm{BW}_{35}$ of the $\mathrm{HBW}_{42}$ line and 4.76 in $\mathrm{BW}_{42}$ of the $\mathrm{HGR}_{1-42}$ line as shown in Table 4. Similar trend of higher realized correlated responses than their expected estimates in males was also obtained for females (Table 5). The realized correlated responses in $\mathrm{GR}_{1-21}$ and $\mathrm{GR}_{1-42}$ were statistically differed than their expected estimates in the line selected for $\mathrm{HBW}_{42}$. Similarly, the realized correlated responses in all body weights from seven up to 42 days of age for the $\mathrm{HGR}_{1-42}$ line except $\mathrm{BW}_{1}$ which significantly positive and higher than the expected estimates, whereas the realized correlated responses in growth rate traits of this line were insignificantly differed than their expected estimates. The highest correlated responses for females were 7.21 and 5.86 for $\mathrm{BW}_{21}$ in the $\mathrm{HBW}_{42}$ and $\mathrm{HGR}_{1-42}$ lines, respectively as shown in Table 5 .

\section{Expected and realized correlated responses for fitness traits}

The realized correlated responses were insignificantly lower than expected estimates for all fitness traits in the line selected for $\mathrm{HBW}_{42}$. Similar trends were observed for fitness traits, except (HTE\%), which indicated highly significant differences favoring realized correlated responses as a result of selection for $\mathrm{HGR}_{1-42}(\mathrm{P} \leq 0.01)$ as shown in Table 6 and Figure 4.

It can be concluded that selection for high growth rate is more effective than selection for body weight because both insignificantly differed from each other for all growth traits and the survivability during the periods from 1-21 and 1-42 days of age. Besides, there are significant differences favoring HGR 42 line for fertility\% and hatchability\% which calculated as a percentage of total eggs or as a percentage of fertile eggs, which can be used as additional indirect goals from selection in that line. 
Gihan, S. Farahat; et al.

Table 5

Fayoum J. Agric. Res. \& Dev., Vol. 21, No. 1, January, 2007 
Table 6. Expected and realized correlated response for fitness traits in $\mathbf{H B W}_{42}$ and HGR 1-42 $_{2}$ lines by generation in Japanese quail.

\begin{tabular}{|c|c|c|c|c|c|c|c|c|}
\hline \multirow{2}{*}{ Line } & \multirow{2}{*}{\multicolumn{2}{|c|}{ Correlated trait }} & \multicolumn{3}{|c|}{ Generation } & \multirow{2}{*}{$\begin{array}{c}\text { Overall } \\
\text { mean }\end{array}$} & \multirow[b]{2}{*}{$\mathbf{b}$} & \multirow{2}{*}{$\begin{array}{l}\text { t-test } \\
\text { sig. }\end{array}$} \\
\hline & & & G1 & G2 & G3 & & & \\
\hline \multirow{18}{*}{$\mathrm{HBW}_{42}$} & \multirow{3}{*}{ Fertility \% } & ECR & -0.02 & -0.13 & -0.40 & -0.183 & $-0.190^{N S}$ & $N S$ \\
\hline & & RCR & 0.08 & 0.07 & 0.11 & 0.087 & & \\
\hline & & ECR- RCR & -0.10 & -0.20 & -0.51 & -0.270 & & \\
\hline & \multirow{3}{*}{ HTE\% } & ECR & 0.11 & 0.56 & 0.01 & 0.227 & $-0.050^{N S}$ & $N S$ \\
\hline & & RCR & 0.07 & 0.02 & 0.08 & 0.057 & & \\
\hline & & ECR- RCR & 0.04 & 0.54 & -0.07 & 0.170 & & \\
\hline & \multirow{3}{*}{ HFE \% } & ECR & 0.20 & 0.82 & 0.53 & 0.517 & $0.165^{N S}$ & $N S$ \\
\hline & & RCR & -0.003 & 0.02 & 0.001 & 0.006 & & \\
\hline & & ECR- RCR & 0.203 & 0.80 & 0.529 & 0.511 & & \\
\hline & \multirow{5}{*}{$\mathrm{S}_{3} \%$} & & & & & & & \\
\hline & & ECR & -0.08 & -0.05 & -0.03 & -0.053 & $0.025^{\mathrm{NS}}$ & $N S$ \\
\hline & & RCR & 0.02 & & 0.01 & 0.011 & & \\
\hline & & & & 0.004 & & & & \\
\hline & & ECR- RCR & $-\mathbf{0 . 1 0}$ & $\overline{0.054}$ & -0.04 & -0.064 & & \\
\hline & \multirow{4}{*}{$S_{6} \%$} & ECR & -0.40 & -0.06 & -0.09 & -0.183 & \multirow[t]{4}{*}{$0.155^{N S}$} & \multirow[t]{4}{*}{$N S$} \\
\hline & & RCR & -0.002 & & -0.002 & -0.002 & & \\
\hline & & & & 0.005 & & & & \\
\hline & & ECR- RCR & -0.392 & $\overline{0.057}$ & -0.088 & -0.181 & & \\
\hline \multirow{15}{*}{ HGR $_{1-42}$} & \multirow{3}{*}{ Fertility\% } & ECR & 0.13 & 0.15 & 0.35 & 0.210 & \multirow[t]{3}{*}{$0.110^{N S}$} & \multirow[t]{3}{*}{$N S$} \\
\hline & & RCR & 0.10 & 0.03 & 0.13 & 0.090 & & \\
\hline & & ECR- RCR & 0.03 & 0.12 & 0.22 & 0.123 & & \\
\hline & \multirow{3}{*}{ НTE\% } & ECR & -0.07 & -0.06 & -0.02 & -0.050 & \multirow[t]{3}{*}{$0.025^{N S}$} & \multirow[t]{3}{*}{$* *$} \\
\hline & & RCR & 0.09 & 0.06 & 0.12 & 0.090 & & \\
\hline & & ECR- RCR & -0.16 & -0.12 & -0.14 & -0.140 & & \\
\hline & \multirow{3}{*}{ HFE \% } & ECR & 0.11 & 0.24 & 0.09 & 0.147 & \multirow[t]{3}{*}{$-0.001^{N S}$} & \multirow[t]{3}{*}{$N S$} \\
\hline & & RCR & 0.02 & 0.05 & 0.03 & 0.033 & & \\
\hline & & ECR- RCR & 0.09 & 0.19 & 0.06 & 0.110 & & \\
\hline & \multirow{3}{*}{$\mathbf{S}_{\mathbf{3}} \%$} & ECR & 0.01 & 0.22 & 0.01 & 0.080 & \multirow[t]{3}{*}{$0.000^{N S}$} & \multirow[t]{3}{*}{$N S$} \\
\hline & & RCR & 0.01 & 0.01 & 0.02 & 0.013 & & \\
\hline & & ECR- RCR & 0.00 & 0.21 & -0.01 & 0.067 & & \\
\hline & & ECR & 0.03 & 0.07 & 0.08 & 0.060 & $0.250^{N S}$ & $N S$ \\
\hline & $\mathrm{S}_{6} \%$ & RCR & 0.01 & 0.02 & 0.001 & 0.010 & & \\
\hline & & ECR- RCR & 0.02 & 0.05 & 0.079 & 0.050 & & \\
\hline
\end{tabular}

$\mathrm{HBW}_{42}$ : selected line for high body weight at 42 days of age, $\mathrm{HGR}_{1-42}$ : selected line for high growth rate from1 to 42 days of age.

NS: not significance, HTE \%: calculated as a percentage of total eggs, HFE \%: calculated as a percentage of fertile eggs, $\mathrm{S}_{3} \%$ and $\mathrm{S}_{6} \%$ : calculated during the first three and six weeks of age, respectively.

ECR: Expected correlated response, RCR: Realized correlated response.

b: regression coefficient for expected correlated responses on generation number and $* *: \mathrm{P} \leq 0.01$.

Fayoum J. Agric. Res. \& Dev., Vol. 21, No. 1, January, 2007 
Gihan, S. Farahat; et al.

Fig. 4

Fayoum J. Agric. Res. \& Dev., Vol. 21, No. 1, January, 2007 
SHORT-TERM SELECTION FOR BODY WEIGHT AND GROWTH.. 209

\section{REFERENCES}

Abdel Fattah, M.H., 2006. Selection for body weight and growth rate in Japanese quail. Ph.D. Thesis, Fac. Agric., Fayoum, Fayoum Univ., Egypt.

Anthony, N.B., K.E. Nestor and W.L. Bacon, 1986. Growth curves of Japanese quail as modified by divergent selection for 4 -week body weight. Poult. Sci. 65: 1825 - 1833.

Anthony, N.B., K.E. Nestor and H. L. Marks, 1996. Short-term selection for 4week body weight in Japanese quail. Poult. Sci. 75: 1192-1197.

Badawy, N.A., K. Saleh., T.M. EI Sayed and R.A. Hassan, 1997. Selection for body weight at 6-week of age in Japanese quail. Second Hungarian Egyptian Poultry Conference 16-19 September. Godollo., Hungary, pp: 199 -214.

Bahie El Deen, M., 1991. Selection and correlated response for dressing percentage in Japanese quail. M. Sc. Thesis, Fac. Agric., Alex. Univ., Egypt.

Bahie EI Deen, M., 1994. Selection indices and crossing as a tool for improvement meat and egg production in Japanese quail. $\mathrm{Ph}$. D. Thesis, Fac. Agric., Alex. Univ., Egypt.

Bahie El Deen, M., 2003. Long-term selection for body weight in Japanese quail under Egyptian conditions 1. Direct response of growth. Egypt. Poult. Sci. 23: 705- 719 .

Barbato, G. F., 1991. Genetic architecture of growth curve parameters in chickens. Theor. Appl. Genet. 83: 24-32.

Barbato, G. F., 1992. Divergent selection for exponential growth rate at 14 or 42 days of age. 1. Early responses. Poult. Sci. 71: 1985-1993.

Benoff, F. H. and J. A. Renden, 1983. Divergent selection for mature body weight in dwarf White Leghorns. 1. Growth and reproductive responses to selection. Poult. Sci. 62: 1931-1937.

Brody, S., 1945. Bioenergetics and Growth. Reinhold Publshing Corp., New York, NT.

Buyse, J., G. P. Janssens and E. Decuypre, 2001. The effects of dietary Lomitine and supplementation on the performance, organ weights and concentrations of broiler chickens reared under a normal or low temperature schedule. Br. Poult. Sci. 42: 230-241.

Darden, J. R. and H. L. Marks, 1988. Divergent selection for growth in Japanese quail under split and complete nutritional environments genetic and correlated response to selection. Poult. Sci. 67: 519 - 529.

Decuypere, E., V. Bruggeman, G. F. Barbato and J., Buyse, 2003. Growth and reproduction problems associated with selection for increased broiler meat production. pp: 13-28. In: Poultry Genetics, Breeding and Biotechnology, edited by Muir. W. M. and Aggrey, S. E, CABI Publishing, London.

Duncan, D.B., 1955. The Multiple Range and Multiple F Test. Biometrics. 11: 1-42

El Fiky, F. A., 1991. Genetic studies on some economic traits in Japanese quail. Ph.D. Thesis, Fac. Agric. Al Azhar Univ., Cairo, Egypt.

El Gindy, E. A., 1984. Selection for increased 8-week body weight in White Baladi chickens. M. Sc. Thesis, Fac. Agric., Cairo Univ., Egypt.

El Hossari, M. A., 1977. Predicted correlated response to selection for some economic characteristics in Fayoumi chicken. A. B. A. 45: 1912.

Fayoum J. Agric. Res. \& Dev., Vol. 21, No. 1, January, 2007 
EI Sayed, T.M., N.S. Isshak and T.A. Fouad, 1995. Growth rate inheritance in Japanese quail. First Egyptian Hungarian Poultry Conference 17-19 septemper, 1995 part $\Pi$.

Emmerson, D.A., 1997. Commercial approaches to genetic selection for growth and feed conversion in domestic poultry. Poult. Sci. 76: 1121-1125.

Falconer, D.S. 1989. Introduction to Quantitative Genetics. $3^{\text {rd }}$ Ed, Longman Group, Essex, England.

Havenstein, G.B., P.R., Ferket, S.E., Scheideler and B.T., Larson, 1994. Growth, livability and feed conversion of 1957 vs 1991 broilers when fed typical 1957 and 1991 broiler diets. Poult. Sci. 73: 1785-1794.

Khan, A.G., R.G. Jaap and A.K. Kanoun, 1975. Body weight response to selection and crossbonding in dwarf and normal broiler type chickens. Poult. Sci. 54: 1239-1244.

Kosba, M.A. and F.N.K. Soliman, 1992. Genetic and phenotypic correlations of body weight and gains at different ages in Japanese quail. Egypt. Poult. Sci. 12: 697-710.

Lerner, I.M., 1958. The genetic basis of selection. John Wiley and Sons, Inc. New York. (As cited in Muir and Goodman, 1964).

Li, Z., K.E. Nestor, Y.M. Saif and J.W. Anderson, 2000. Antibody responses to sheep red blood cell and Brucella abortus antigens in a turkey line selected for increased body weight and its randombred control. Poult. Sci. 79: 804-809.

Marks, H.L. 1979. Changes in unselected traits accompanying long-term selection for four-week body weight in Japanese quail. Poult. Sci. 58: 269 $-274$.

Marks, H.L., 1996. Long-term selection for body weight in Japanese quail under different environments. Poult. Sci. 75: 1198 - 1203.

Nestor, K.E. and W.L. Bacon, 1982. Divergent selection for body weight and yolk precursor in Coturnix coturnix japonica. 3. Correlated responses in mortality and reproduction traits and adult body weight. Poult. Sci. 61: 2137-2142.

Nestor, K.E., W.L. Bacon, N.B. Anthory, D.O. Nable, 1996. Divergent selection for body weight and yolk precursor in Coturnix coturnix japonica. 10. Response to selection over thirty generations. Poult. Sci. 75: 303-310.

Nicholson, D., 1998. The broiler industry's partner into the new millennium. World's Poult. Sci. J. 3: 271-278.

Sefton, A.E. and Siegel, P.B., 1974. Inheritance of body weight in Japanese quail. Poult. Sci. 53: $1597-1603$.

Shalan, H.M., 1998. Independent culling levels selection and crossing for improving meat and egg production in Japanese quail. Ph. D. Thesis, Fac. Agric, Alex., Univ., Egypt.

Siegel, P.B., 1963. Selection for breast angle at eight weeks of age: 2. Correlated responses for feathering, body weighs and reproductive characteristics. Poult. Sci. 42: 437 - 449.

SPSS Inc., 1999. User's Guide: Statistics. Version 10. SPSS Inc., Chicago, IL, USA.

Suda, Y. and S. Okamoto, 2003. Long-term selection for small body weight in Japanese quail. 2: changes in reproductive traits from 60 to $65^{\text {th }}$ generations. Japanese Poult. Sci. 40: 30-38.

Fayoum J. Agric. Res. \& Dev., Vol. 21, No. 1, January, 2007 
SHORT-TERM SELECTION FOR BODY WEIGHT AND GROWTH.. 211

Tawfuek, F.A. 1995. Growth rate inheritance in Japanese quail. M. Sc. Thesis, Fac. Agric., Tanta Univ., Egypt.

$$
\begin{aligned}
& \text { الاتتخاب على المدى القصير لزيادة وزن الجسم ومعدل النمو فى السمان اليابانى } \\
& \text { r الاستجابة المرتبطة } \\
& \text { جيهان شعبان فرحات وإنصاف أحمد الفل و محمد حامد عبد الفتاح* } \\
& \text { ونبيل على حطبة ومحمد عبد الصمد خليفة الصنة } \\
& \text { كلبة الزراعة بالفيوم- قنس إنتاج الدو اجن - جامعة الفيدة الفيوم }
\end{aligned}
$$

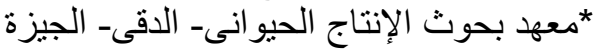

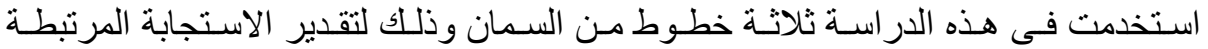

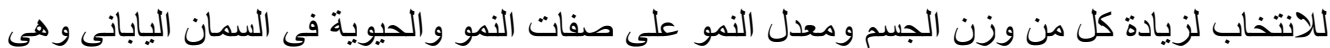

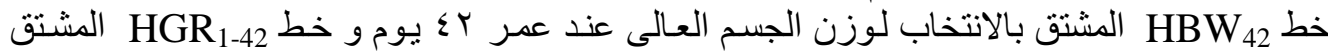

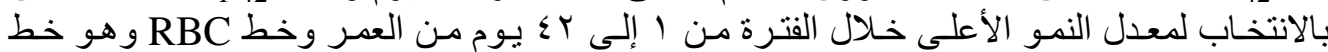

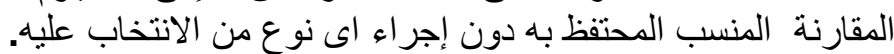

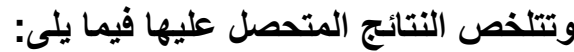

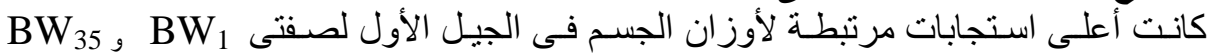

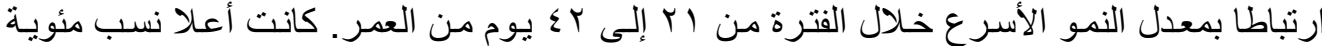

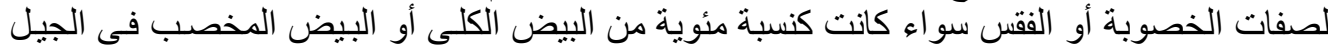

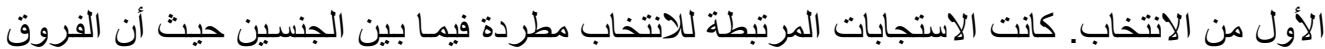

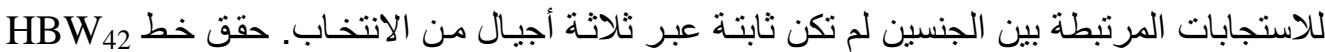
أعلا قيم لكلا من صفات

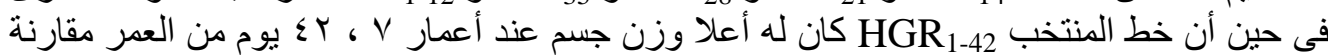

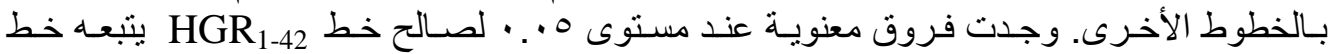

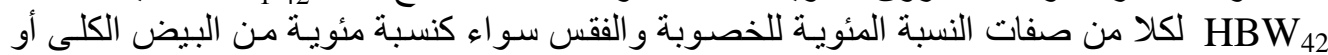

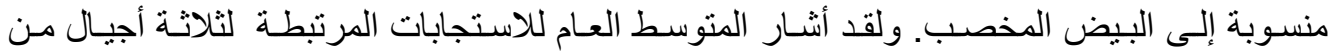

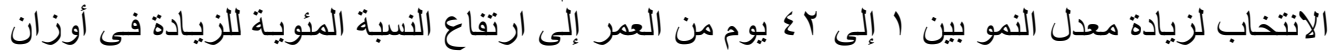

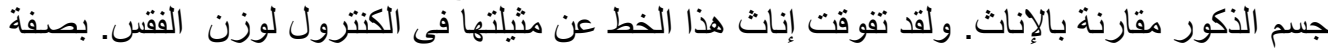

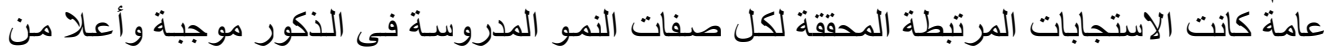

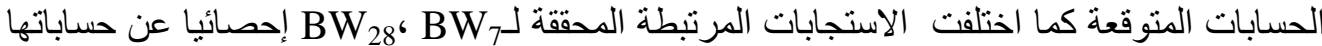

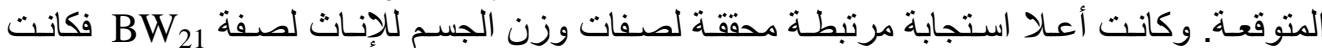

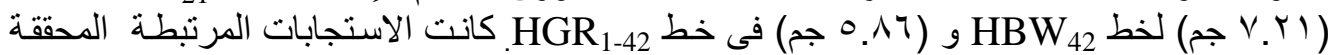

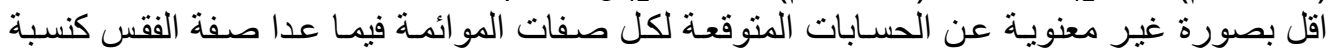

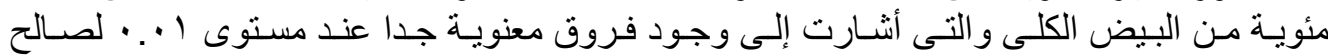

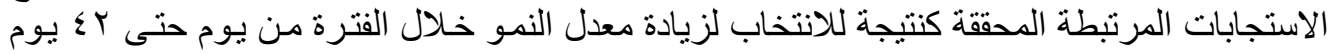

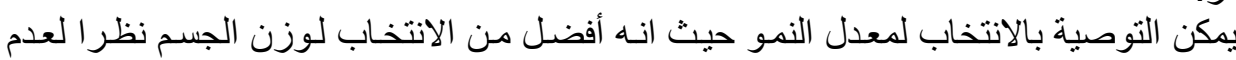

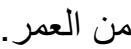

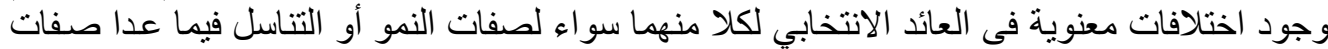

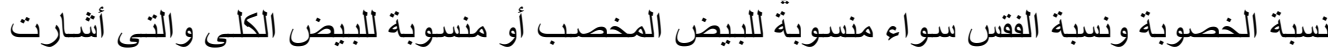

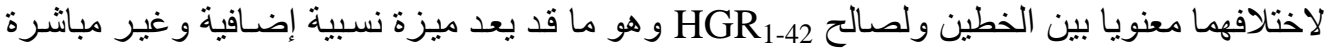

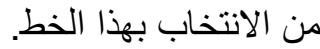

Fayoum J. Agric. Res. \& Dev., Vol. 21, No. 1, January, 2007 